\title{
Pengaruh Edukasi Terhadap Penurunan Risiko Penyakit Kardiovaskur Pada Pria dengan Obesitas
}

\author{
Dewi Rahmawati, Irwan Setiabudi, Astrid Praditina Susilo, Lisa Aditama \\ Fakultas Farmasi, Universitas Mulawarman, Samarinda, Kalimantan Timur \\ dewi@farmasi.unmul.ac.id
}

\begin{abstract}
ABSTRAK
Prevalensi obesitas di Indonesia telah meningkat beberapa tahun terakhir. Meningkatnya prevalensi obesitas disebabkan oleh banyaknya jumlah makanan yang terjangkau harganya dan gaya hidup aktivitas menetap. Melihat besarnya dampak dari obesitas, maka perlu dilakukan usaha-usaha pencegahan maupun penanggulangan. Penanggulangan obesitas dapat dilakukan salah satunya dengan modifikasi gaya hidup. Modifikasi gaya hidup adalah suatu perubahan perilaku, yang mana gaya hidup merupakan perilaku individu yang diwujudkan dalam bentuk aktivitas, minat dan pandangan individu yang di pengaruhi oleh interaksi dengan lingkungan sekitar. Modifikasi gaya hidup dapat diwujudkan dalam bentuk edukasi. Penelitian ini bertujuan untuk mengetahui pengaruh edukasi terhadap fakor risiko kardiovaskular pada pasien obesitas. Penelitian ini merupakan penelitian kuantitatif menggunakan metode Beforeafter Study untuk menguji efektivitas dari edukasi pada 23 karyawan pria Universitas Surabaya yang mengalami obesitas. Faktor risiko kardiovaskular diukur dengan menggunakan Framingham Scoring. Semua pengukuran dilakukan sebelum dan sesudah pemberian intervensi. Hasil penelitian ini terdapat perbedaan yang signifikan sebelum dan sesudah diedukasi pada faktor risiko kardiovaskular berdasarkan body mass index (BMI) dan profil lipid $(2,10 \% \pm 0,01$ and $1,78 \% \pm 0,02 \mathrm{p}=0,00)$. Metode edukasi lisan dapat digunakan sebagai alat edukasi dan informasi bagi pasien yang mengalami obesitas.
\end{abstract}

Kata Kunci: Edukasi lisan, Faktor risiko kardiovaskular, Obesitas.

\section{Pendahuluan}

Prevalensi obesitas di Indonesia telah meningkat beberapa tahun terakhir. Data terakhir menurut Himpunan Studi Obesitas Indonesia (HISOBI), menunjukkan prevalensi obesitas di Indonesia sebesar 9,16\% pada pria, dan $11,02 \%$ wanita. Meningkatnya prevalensi obesitas disebabkan oleh banyaknya jumlah makanan yang terjangkau harganya, dan gaya hidup aktivitas menetap, seperti menonton televisi, main game di komputer. Adanya peningkatan teknologi ini menyebabkan makanan dapat diproduksi dalam jumlah besar dan harganya murah, serta mengakibatkan banyak pekerjaan dapat dilakukan secara otomatis (inaktivitas fisik). Obesitas telah menjadi masalah epidemik yang global, tidak hanya di Indonesia saja, namun terjadi di seluruh dunia. $^{1}$

Obesitas juga menjadi pusat perhatian sebagai faktor risiko penyakit arteri-koroner, dan peningkatan laju kesakitan dan kematian. Selain itu obesitas merupakan penyumbang utama beban global penyakit kronis dan kecacatan, sebagai faktor risiko untuk kondisi medis seperti penyakit jantung, diabetes, hipertensi, stroke, emboli paru, kanker usus besar, kanker hati, 
kanker pankrease, kanker rektum, osteoatritis, penyakit kandung empedu dan gangguan pernafasan. Penyakitpenyakit tersebut merupakan penyakit yang tidak menular, yang diperkirakan akan meningkat dari 28,1 juta menjadi 49,71 juta pertahun, peningkatan jumlah absolut sebesar $77 \%$. Penyakit jantung iskemia diperkirakan akan menjadi penyakit yang terkemuka di seluruh dunia, dan menjadi beban penyebab penyakit pada tahun 2020.,3,4 Pria memiliki risiko penyakit kardiovaskular lebih besar dibandingkan wanita sebelum menopause, akan tetapi faktor risiko wanita akan meningkat lima sampai sepuluh tahun postmenopause, sehingga faktor risiko menjadi sama dengan pria. Hal ini karena pada wanita sebelum menopause memiliki hormon esterogen yang berfungsi sebagai cardioprotector pada wanita. Melihat begitu besarnya dampak dari obesitas, maka perlu dilakukan usaha-usaha untuk pencegahan maupun penanggulangan sindroma metabolik. Penanggulangan dan pencegahan sindroma metabolik tidaklah mudah seperti yang dibayangkan. Banyak komponen yang terlibat di dalamnya, seperti faktor psikososial, gaya hidup, sosial ekonomi dan kebutuhan individu sendiri. Oleh karena itu penanggulangan obesitas tidak hanya dilakukan dengan penghentian asupan makanan. Penanggulangan obesitas dapat dilakukan salah satunya dengan modifikasi gaya hidup. ${ }^{5,6,7}$ Intervensi modifikasi gaya hidup dapat diwujudkan dalam bentuk edukasi yang merupakan bagian integral dari kegiatan kefarmasian. Kegiatan pelayanan kefarmasian pada saat ini bergeser orientasinya mengacu kepada pelayanan kefarmasian (pharmaceutical care), yang semula hanya berfokus pada pengelolaan obat sebagai komoditi menjadi pelayanan komprehensif, yang bertujuan untuk meningkatkan kualitas hidup dari pasien. Edukasi lisan serta modul "Pocket Activity " ini dipakai karena menguunakan dua metode edukasi yaitu lisan dan non lisan yang bekerja secara sinergis dalam memberikan informasi dan modul ini berisi secara detail dan poin-poin edukasi yang ingin diberikan dapat tersampaikan dengan baik sehingga dapat digunakan oleh pasien dengan mudah.

\section{Metode}

Penelitian ini berbentuk before-after study, yang akan dilakukan secara kuantitatif untuk mengetahui pengaruh edukasi, dengan modul "Pocket Activity" dalam modifikasi gaya hidup pada faktor risiko kardiovaskular penderita pria dengan obesitas. Edukasi modifikasi gaya hidup dilakukan selama tiga bulan, selain edukasi modifikasi gaya hidup berupa edukasi lisan, masing-masing juga mendapatkan buku panduan yaitu modul "Pocket Activity" untuk penurunan berat badan. Lokasi yang digunakan dalam penelitian ini adalah di Universitas Surabaya. Waktu penelitian berlangsung selama tiga bulan. sampel yang digunakan sejumlah 30 orang yang masuk kriteria inklusi dan ekslusi dari penelitian.

Kriteria inklusi:

a. Pasien obesitas dengan lingkar pinggang $>90 \mathrm{~cm}$ dan $\mathrm{BMI} \geq 30$ $\mathrm{kg} / \mathrm{m}^{2}$

b. Bersedia mengikuti edukasi modifikasi gaya hidup

Kriteria eksklusi:

a. Pasien dengan Penyakit Jantung Koroner

b. Pasien dengan Diabetes Mellitus

c. Pasien yang mengkonsumsi obat penurun berat badan

\section{Hasil dan Pembahasan}

Penelitian

kuantitatif, dilaksanakan selama bulan Okotober 2012 - Januari 2013. Tahapan ini terdiri dari perekrutan partisipan, penilaian awal, edukasi dan penilaian akhir. Keseluruhan proses dilaksanakan di 
kampus Universitas Surabaya Tenggilis dan Ngagel. faktor risiko kardiovaskular pada partisipan ini dipengaruhi oleh banyak faktor antara lain usia, jenis kelamin, tingkat pendidikan, riwayat sosial minum kopi, riwayat sosial berolahraga, riwayat penyakit keluarga, dan obat-obat yang dikonsumsi tiga bulan terakhir ini. Hasil ini dapat dilihat pada tabel 1 .

Tabel 1. Demografi dan karakteristik partisipan

\begin{tabular}{ll}
\hline Demografi & Partisipan $(\mathrm{n}=23)$ \\
\hline Usia(mean \pm SD) & $44,56 \pm 6,49$ \\
Body Mass Index (BMI) (mean \pm SD) & $31,97 \pm 2,59$ \\
Riwayat Sosial Merokok & \\
a. Tidak merokok & $18(78,26 \%)$ \\
b. Merokok & $5(21,74 \%)$ \\
Riwayat Sosial Minum Kopi & \\
a. Tidak minum kopi & $9(39,13 \%)$ \\
b. $\leq 1$ cangkir/hari & $1(4,35 \%)$ \\
c. 1-3 cangkir/hari & $12(53,17 \%)$ \\
d. $\geq 4$ cangkir/hari & $1(4,35 \%)$ \\
Riwayat Sosial Melakukan Olahraga & \\
a. Tidak olahraga & $8(34,78 \%)$ \\
b. $\leq 1 \times /$ minggu & $4(17,39 \%)$ \\
c. 1-3 $\times /$ minggu & $3(13,04 \%)$ \\
d. $\geq 4 \times /$ minggu & $8(34,78 \%)$ \\
Riwayat Penyakit Keluarga & \\
a. Jantung & $5(21,74 \%)$ \\
b. Diabetes & $3(13,04 \%)$ \\
c. Hipertensi & $5(21,74 \%)$ \\
d. Lipid & $3(21,72 \%)$ \\
e. Ginjal & $1(4,35 \%)$ \\
f. Asam Urat & $1(4,35 \%)$ \\
g. Osteoarthritis & $1(4,35 \%)$ \\
Tingkat Pendidikan & $7(30,43 \%)$ \\
a. Pendidikan Rendah & $16(69,56 \%)$ \\
b. Pendidikan Tinggi & $1(4,35 \%)$ \\
Obat yang dikonsumsi 3 bulan terakhir & $3(13,04 \%)$ \\
a. Penurun Lipid & $0(0 \%)$ \\
b. Anti-Hipertensi & $3(13,04 \%)$ \\
c. Kortikosteroid & \\
d. Obat lainnya & \\
\hline &
\end{tabular}


Tabel 2 Uji normalitas Framingham scoring faktor risiko kardiovaskular berdasarkan BMI dan profil lipid

Tests of Normality

\begin{tabular}{lllllll}
\hline \multicolumn{5}{c}{ Kolmogorov-Smirnov $^{\mathrm{a}}$} & \multicolumn{3}{l}{ Shapiro-Wilk } \\
\hline & Statistic & Df & Sig. & Statistic & Df & Sig. \\
GenBMI & .180 & 23 & .051 & .889 & 23 & .015 \\
B & & & & & & \\
GenBMI & .161 & 23 & .126 & .884 & 23 & .012 \\
A & & & & & & \\
\hline
\end{tabular}

a. Lilliefors Significance Correction

Tests of Normality

\begin{tabular}{rllllll} 
& \multicolumn{3}{c}{ Kolmogorov-Smirnov $^{\mathrm{a}}$} & \multicolumn{2}{l}{ Shapiro-Wilk } \\
Statistic & Df & Sig. & Statistic & Df & Sig. \\
GenLipB & .200 & 23 & .017 & .896 & 23 & .021 \\
GenLipA & .274 & 23 & .000 & .846 & 23 & .002
\end{tabular}

a. Lilliefors Significance Correction

1. Framingham Scoring faktor risiko kardiovaskular berdasarkan BMI sebelum dan sesudah diedukasi

Uji normalitas dengan ShapiroWilk menunjukkan nilai Shapiro-Wilk faktor risiko kardiovasukar berdasarkan BMI sebelum diedukasi adalah 0,89 dan nilai Shapiro-Wilk faktor risiko kardiovaskular berdasarkan BMI sesudah diedukasi adalah 0,884 dengan masing-masing nilai probabilitas $\mathrm{p}=0.01$ sebelum diedukasi dan $\mathrm{p}=0.01$ sesudah diedukasi. Dengan probabilitas $<0,05$, maka dapat disimpulkan bahwa data berdistribusi tidak normal.
2. Framingham Scoring faktor risiko kardiovaskular berdasarkan profil lipid sebelum dan sesudah diedukasi

Uji normalitas dengan ShapiroWilk menunjukkan nilai Shapiro-Wilk faktor risiko kardiovasukar berdasarkan profil lipid sebelum diedukasi adalah 0,89 dan nilai Shapiro-Wilk faktor risiko kardiovaskular berdasarkan profil lipid sesudah diedukasi adalah 0,84 dengan masing-masing nilai probabilitas $\mathrm{p}=0.02$ sebelum diedukasi dan $\mathrm{p}=0.02$ sesudah diedukasi. Dengan probabilitas <0,05, maka dapat disimpulkan bahwa data berdistribusi tidak normal.

Tabel 1.3 Hasil analisis Framingham Scoring faktor risiko kardiovaskular berdasarkan BMI partisipan sebelum dan sesudah dilakukan edukasi dengan metode Wilcoxon signed rank test

\begin{tabular}{|l|l|l|l|}
\hline & $\mathrm{N}$ & $\begin{array}{l}\text { Median } \\
\text { (minimum-maksimum) }\end{array}$ & $P$ \\
\hline $\begin{array}{l}\text { Faktor risiko kardiovaskular } \\
\text { berdasrkan BMI sebelum edukasi }\end{array}$ & 23 & $12,10(2,30-30,00)$ & 0.000 \\
\cline { 1 - 1 } $\begin{array}{l}\text { Faktor risiko kardiovaskular } \\
\text { berdasarkan BMI sebelum edukasi }\end{array}$ & 23 & $10,40(2,00-27,00)$ & \\
\hline
\end{tabular}


Berdasarkan uji Wilcoxon

signed rank test nilai signifikansi sebesar $\mathrm{p}=0,000$ dengan penurunan rata-rata risiko kardiovaskular sebesar $2,10 \% \pm 0,014$ yang mana nilai $\mathrm{p}<0,05$.

Tabel 1.4 Hasil analisis Framingham Scoring faktor risiko kardiovaskular berdasarkan profil lipid partisipan sebelum dan sesudah dilakukan edukasi dengan metode Wilcoxon signed rank test

\begin{tabular}{|l|l|l|l|}
\hline & $\mathrm{N}$ & $\begin{array}{l}\text { Median } \\
\text { (minimum-maksimum) }\end{array}$ & $p$ \\
\hline $\begin{array}{l}\text { Faktor risiko kardiovaskular berdasarkan } \\
\text { profil lipid sebelum edukasi }\end{array}$ & 23 & $10,60(1,70-29,90)$ & 0.000 \\
\cline { 1 - 1 } $\begin{array}{l}\text { Faktor risiko kardiovaskular berdasarkan } \\
\text { profil lipid sesudahedukasi }\end{array}$ & 23 & $8,90(1,60-25,90)$ & \\
\hline
\end{tabular}

Berdasarkan uji Wilcoxon signed rank test nilai signifikansi sebesar $\mathrm{p}=0,000$ dengan penurunan ratarata risiko kardiovaskular sebesar $1,78 \% \pm 0,019$ yang mana nilai $\mathrm{p}<0,05$. Pada penelitian ini pengukuran faktor risiko kardiovaskular menggunakan Framingham Scoring memerlukan beberapa data laboratorium di antaranya pengukuran kadar gula darah puasa, profil lipid: HDL, LDL dengan menggunakan metode direct, TG, dan total cholesterol. Yang mana oleh laboratorium PRODIA sebelum dilakukan penelitian, dilakukan pemantapan mutu dengan menggunakan serum kontrol terlebih dahulu sehingga data dan hasil yang diperoleh valid. Obesitas merupakan kontributor utama beban global dari penyakit kronis dan kecacatan, maka diperlukan usaha-usaha untuk pencegahan maupun penanggulangannya. ${ }^{1,5,6,7}$ Usaha yang dapat dilakukan adalah dengan modifikasi gaya hidup dengan cara memberikan edukasi. ${ }^{8}$ Pada penelitian ini intervensi yang diberikan adalah sebuah kombinasi metode edukasi lisan dan non lisan, berupa edukasi lisan dengan presentasi dan modul "Pocket
Activity" berbentuk kalender meja yang akan bekerja secara sinergis. ${ }^{9}$ penelitian ini akan memberikan pengetahuan tambahan bagi pasien. Pengetahuan tambahan ini yang akan mempengaruhi persepsi seseorang sehingga dapat mempengaruhi niat dan perilakunya untuk mencoba melakukan perubahan perilaku dari perilaku terdahulu. ${ }^{8,10}$ Perubahan perilaku yang positif ini maka akan memberikan dampak penurunan faktor risiko kardiovaskular 8,10,11 yang selanjutnya akan memperkecil angka kejadian dan kematian akibat penyakit kardiovaskular pada pasien yang mengalami obesitas.

\section{Kesimpulan dan Saran}

Metode edukasi lisan dengan modul "Pocket Activity" memberikan pengaruh yang bermakna pada faktor risiko kardiovaskular pada pasien pria dengan obesitas.

Saran dapat dilakukan penelitian dengan intervensi serupa dengan rancangan penelitian $R C T$ dengan subyek penelitian pria obesitas. Dan melakukan penelitian lebih lanjut nmengenai penelitian ini dalam jangka waktu yang lebih lama. 
Daftar Pustaka

1. Grundy SM. Obesity, Metabolic Syndrome, and Cardiovascular Disease. J Clin Endocrinol 2004; 89 (6): 2595-2600

2. Poirier P, Eckcel RH. Obesity and cardiovascular disease. Current Atherosclerosis Reports. 2002; 4: 448-53.

3. Poirier P, Giles TD, Bray GA, Hong Y, Stern JS, Pi-Sunyer FX, Eckel RH. Obesity and Cardiovascular Disease: pathophysiology, evaluation, and effect of weight loss: an update of the 1997 American Heart Association Scientific Statement on Obesity and Heart Disease From the Obesity Committee of the Council on Nutrition, Physical Activity, and Metabolism. Circulation. 2006; 113: 898-918.

4. Calza S, Decarli A, Ferraroni M. Obesity and prevelence of chronic disease in the 1999-2000 Italian National Health Survey. BMC Public Health. 2008; 8 (140): 1-9.

5. Third Report of the National Cholesterol Education Program (NCEP) Expert Panel on Detection, Evaluation, and Treatment of High Blood Cholesterol in Adults (Adult Treatment Panel III)- Final Report. National Institutes of Health. 2002
6. Santo AC, Ebrahim S, Barros H. Gender, socio-economic status and metabolic syndrome in middle-age and old adults. BMC Public Health. 2008; 8:62: 1-8.

7. Sodjinou R, Agueh V, Fayoni B, Delisle H. Obesity and cardiometabolic risk factor in urban adult of Benin: relationship with socioeconomic status, urbanisation, and lifestyle patterns. BMC Public Health. 2008; 8:84: 1-13.

8. Ogden J. Health Psycology A Textbook. 4th ed. USA: Open University Press; 2007.

9. Broekhuizen $\mathrm{K}$, van Poppel $\mathrm{MN}$, Koppers LL, Brug J, van Mechelen W. A tailored lifestyle intervention to reduce the cardiovascular risk factor of individual with Familial Hypercholesterolemia (FH): design of the PRO-FIT randomised controlled trial. BMC Public Health. 2010; 10 (69): 1-10.

10. Shumaker SA, Ockene JK, Riekert KA, editors. The Handbook of Health Behavior Change. 3rd ed. New York: Springer Publishing Company, LLC; 2009

11. Brannon L, Feist J. Health Psycology; An Introduction to Behavior and Health. 7th ed. UA: Thomsom Wadsoworth; 2007. 